\title{
London 2012 Olympics and the Power of the British Trade Unions: A Golden Opportunity?
}

\author{
Helen Russell, GLU Alumna, United Kingdom
}

\begin{abstract}
Since their modern inception in 1896, the Olympics have grown in size and stature to become one of the most important mega-sport events. However, unlike other mega-sport events the Olympics has its own value-laden philosophy of "Olympism", advocating sport as a vehicle for social change. This paper utilises Eric Batstone's (1988) three-fold power schema of disruptive potential, labour scarcity and political influence to explore the impact of London 2012 on the power of the British unions. To achieve this, it draws on a comparative study of the National Union of Rail, Maritime and Transport Workers (RMT) and the Musicians' Union (MU). Based on findings generated from interviews and secondary-data analysis this paper will argue that the collective bargaining results of unions in the run-up to and during the 2012 Olympic Games were a reflection of the individual unions' preexisting power - those that had more disruptive, labour scarcity or political power prior to the Games were able to win more benefits for their members, whereas those with less were either less successful or did not succeed at all in their negotiations. In addition, when evaluating the power sources, an "Olympic factor" can be observed, which produces a differentiated impact on the power resources of the unions.
\end{abstract}

\section{KEY WORDS}

Olympics, RMT, Musicians’ Union, Power, London 2012

\section{Introduction}

The first modern Olympic Games were held in Athens, Greece, in 1896 and brought together athletes from fourteen countries. Since this inception, the modern Games have grown in size and stature, leading some scholars to refer to them as the world's largest peacetime event (Cashman and Hughes, 1999). They are, along with the FIFA World Cup, one of the most important international mega-sport events (Roche, 2000). A total of 204 nations competed at London 2012, amounting to 10568 athletes (IOC, 2012).

Not only did Pierre de Fredy, Baron de Coubertin, establish the first modern Games but he also created the philosophy of "Olympism" as first enshrined in the Olympic Charter, published in 1908. The current Charter is much more developed than the original Annuaire du Comite International Olympique but still states that Olympism is a philosophy of life "exalting and combining in a balanced whole the qualities of body, will and mind" (IOC, 2013: 11). The idea of Olympism goes beyond competition as it advocates sport as a method of creating social change. Enshrined in the Charter is the idea that the goal of the Olympic Movement is to "contribute to building a peaceful and better 
world" through sport (IOC, 2013: 11). Thus, since their first modern inception in 1896, the Olympics have been linked to a philosophy which argues that a fundamental goal of the Games is to generate positive societal impacts outside of the immediate sporting competitions. Of course, the extent to which this positive impact occurs, or whether it occurs at all, is the subject of much debate. Not surprisingly the International Olympic Committee (IOC) argues that the Olympic Games have many positive impacts for the host countries, most significantly positive economic impacts.

Despite the fact that criticism of the Olympic Games is often considered to be irresponsible (Hiller, 1989), or in the case of the Sydney Games unpatriotic (Waitt, 1999), in the run-up to and during recent Games, trade unions and other civic organisations have voiced concern about the impact of the events on workers, and have even used the Games as a platform for protest (Timms, 2012). Many unions organised around London 2012 to attempt to win benefits for the workers employed in the Olympics industry and the wider British society.

This paper utilises Eric Batstone's (1988) three-fold power schema of disruptive potential, labour scarcity and political influence to explore the impact of London 2012 on the power of the British unions, through a comparative study of the National Union of Rail, Maritime and Transport Workers (RMT) and the Musicians' Union (MU). The article draws on findings generated from semistructured interviews and secondary-data analysis to argue that unions that had more disruptive, labour scarcity or political power prior to the Games were able to win more benefits for their members, whereas those with less were either less successful or did not succeed at all in their negotiations. In addition the article will show that when evaluating the power sources an "Olympic factor" can be observed which produces a differentiated impact on the power resources of trade unions.

The article will first consider the impact of the Olympics on the terms and conditions of members of the RMT and the Musicians' Union. It will then use Batstone's three power sources to show that they can explain the differentials in the results of the two unions, and that there is an "Olympic factor" which impacts power resources. The article concludes by highlighting implications for trade union organising around the Olympics in an attempt to help unions identify how they can potentially increase leverage over Olympic organisations, governments and employers in the run-up to and during the Games.

\section{London 2012, the RMT and the Musicians' Union}

The estimated total figure of people employed in the delivery of the Games was 200000 (Olympic.org, 2012). By the time of the London 2012 opening ceremony, 46000 people had worked on building the Olympic Park and the Athletes' village. The London Organising Committee for the Olympic and Paralympic Games (LOCOG) recruited and trained over 8000 directly employed staff, more than 100000 contracted staff and around 70000 unpaid volunteers (London 2012 Equality and Diversity Forum, 2013). This does not include those employed indirectly in the delivery of the Games, with many workers employed in sectors that serviced the event, including those in the tourism, retail, transport and entertainment sectors. The number of people employed in London during the three months of the Games was 3884 million, an increase of 54000 on the previous quarter and 147000 from the same period in 2011 (Office for National Statistics, 2012a).

The British Trades Union Congress (TUC) supported the London bid to host the Olympic

Global Labour Journal, 2016, 7(1), Page 36 
Games following an address made by Lord Coe, the bid committee Chair, at the 2004 TUC Congress. Lord Coe emphasised the importance of trade union support for the bid and delivery of the Games, and also gave a commitment for a framework agreement with unions. The vital role of the unions was also affirmed at the Congress by the London Mayor, Ken Livingston (TUC, 2013). From an early stage the TUC worked to negotiate a set of agreements on employment terms and conditions with the Olympic Delivery Authority (ODA) and LOCOG. Three working documents were agreed: a Principles of Co-operation, Volunteer Protocol and a Games Time Grievance Resolution Protocol. Among other things the Principles of Co-operation committed the organisers to paying the London Living Wage, recognising existing national or sector collective agreements, allowing union access to Olympic sites and providing decent training for employees (TUC, 2012). In addition, a number of individual unions campaigned and negotiated around terms and conditions specific to their sector including, among others, the RMT and Unite in the transport sector, the Union of Construction, Allied Trades and Technicians (UCATT) and Unite in the construction sector, the Public and Commercial Services Union (PCS) in the civil service sector, the Union of Shop, Distributive and Allied Workers (USDAW) in the retail sector, and the Musicians' Union and Equity in the entertainment sector.

Arguably the most successful union in terms of benefits collectively bargained during the Olympic period was the RMT, which has almost 80000 members throughout the transport sector, including workers on mainline and underground railways, buses, road haulage and shipping; it currently negotiates with over 150 transport-sector companies (RMT, 2014). The RMT, alongside the Associated Society of Locomotive Engineers and Firemen (ASLEF), managed to secure bonuses for the majority of its members in the form of either a one-off payment or an increase in pay for the period, ranging from $£ 2500$ to $£ 300$ depending on the sector. In addition, the RMT managed to stave off employer proposals to make the payment of a bonus conditional on temporary changes to the Framework Agreements, which enshrine the terms and conditions of staff. This resulted in an agreement with the London Underground that no staff would be forced to work outside of the Agreement. While ASLEF and the Transport Salaried Staff Association (TSSA) agreed to the employers' demand, the RMT refused to accept any changes to the Framework Agreements, arguing that it could lead to a long-term deterioration in terms and conditions. While there is not space in this article to examine in depth the results of collective bargaining across different occupational groups within the transport sector, it should be noted that the RMT was not successful across all the occupational groups that they represent. For example, while securing bonuses as high as $f^{2} 500$ for workers on the Docklands Light Railway and $f, 1000$ on the London Underground, the union was not able to secure bonuses for cleaners working on these services. In addition, the union was unable to negotiate a bonus for staff directly employed by Transport for London, staff employed by the contractor Cubic Transportation Services and workers on South West and Greater Anglia train services.

Musicians were an essential part of the Olympic opening and closing ceremonies as well as events in the Olympic village. There were an estimated 6000 performers including 1000 drummers and 500 paid musicians across the opening and closing ceremonies (Musicians' Union, 2012a). The Musicians' Union represents 30000 members, working in all areas of the music industry. In the runup to the Olympics the union had two major concerns - the use of recorded instead of live music at the Olympic ceremonies, and the non-payment of professional musicians at the Olympic ceremonies and events in the Olympic Park. The union met with LOCOG to raise their concerns, and argued 
that it was possible to use live music on such a large scale. However, they were unable to convince the organisers, and the majority of the music used was pre-recorded. The union also launched a campaign after they were informed by members in April 2012 that professional musicians were being asked to perform at Olympic events, including hospitality events in the Olympic Park, without being paid. They argued that this contravened the Principles of Co-operation and Volunteer Protocol agreed between the TUC, the ODA and LOCOG, which stated that professional workers would be paid for their services and were distinct from the unpaid volunteer workforce. The union also claimed that it breached an understanding made with the Olympics Ceremonies Team that entertainers at the opening and closing ceremonies, welcoming ceremonies and medal presentations would fall into one of three categories: the established high-profile performers who would receive only expenses; paid professional performers who would be paid at union-agreed rates; and volunteers who would work in line with the Volunteer Protocol (TUC, 2013). In response the union lobbied LOCOG on the issue, asked members to report requests to work for free to the union and launched the "Work not Play" campaign, but did not organise a ballot for any industrial action. They urged members not to work without payment but when members, in line with this Musicians' Union policy, requested payment from LOCOG they often lost the engagement. As Horace Trubridge, Assistant General Secretary of the Musicians' Union explained:

Some of the musicians who were approached by LOCOG, when they responded to say "I'm a member of the Musicians' Union, I need to be paid", never heard back, they were immediately abandoned. I don't think they (LOCOG) went as far as to approach artists on the basis of asking them if they were members or not but it got very close to that at the time (Interview, Trubridge, 2015).

While they were successful in negotiating payment for artists who took part in an event organised by Universal Music, overall the union was not successful in its efforts to get payment for all professional musicians in line with the Principles of Co-operation (Interview, Trubridge, 2015).

\section{Sources of Union Power during the Olympics}

One of the most useful theoretical frameworks for considering the power of trade unions, and in particular the RMT and the Musicians' Union, is that of Eric Batstone (1988) who argues that there are three power resources of workers: disruptive potential, labour scarcity and political power. According to Batstone, disruptive power depends on a number of factors related to the occupational group. First, the level of disruptive power depends on the centrality of an occupational group to manufacturing a product or delivering a service, the timeframe for delivering a service or product and the attention of outside observers on the service. It also depends greatly on how organised the workers are and how easily they can be mobilised to take action. Labour scarcity is measured by the level of skills required to do the work and the availability of substitute labour. The higher the skills requirement and the lower the availability of replacement labour, the higher the occupational power. Political power of an occupational group depends on the ability of a union to change and influence public opinion. This relates on the one hand to policy makers such as political leaders, political parties and international government agencies, but also the ability to influence the opinion of normal members of the public. 
Batstone's threefold theory of collective power provides a simple way to understand the power of unions and can explain the differentials in the power of different unions representing different occupational groups during London 2012. Those that had high levels of the three power sources were able to negotiate better deals for their members than those that did not have a comparable level of power.

The Musicians' Union were the least successful union in collective bargaining during the Games, in that they were unable even to secure payment for professional musicians. This is very different from the RMT, who were able to secure Olympic bonuses for most of their members, which significantly increased their take-home pay. This variance can be explained by the difference in the levels of disruptive, labour scarcity and political power held by the two unions.

\section{Disruptive Power}

The most obvious measure of a union's disruptive power is how essential the occupational groups are to the delivery of a service or the production of a good and therefore the potential impact on a service if industrial action is taken. The RMT has a particularly high level of disruptive power, which contributed the most to its ability to negotiate Olympic bonuses for the majority of its members. The need to deliver the Olympics on time and within a certain timeframe was the factor that contributed to the disruptive power of the RMT, as a functioning transport system was fundamental to the successful running of London 2012. As Sharon Allen, RMT Learning Development Worker, highlighted:

There was a general fear, among London Underground and Transport for London, that if there was a major dispute it would be completely devastating... Any industrial action on the transport network would have had a very profound effect on the Olympics. So I think there was a fear of industrial action, although I'm not sure the employer would be willing to admit to that (Interview, Allen, 2014).

The Games were to be staged at thirty-four competition venues across the UK so functioning transport links to and between the venues were essential for the delivery and smooth running of the Games. There were 7.4 million ticketed spectators for the Olympic Games, of which 6.25 million attended events in London. There were also an estimated 1.8 million non-ticket events spectators. The Paralympics had 2.7 million ticketed spectators and around 100000 non-ticket event spectators (Transport for London, 2012a: 3). The majority of these spectators planned to use the public transport system to reach the event sites, with estimates prior to the Games suggesting that 80 per cent of spectators would use either the Underground or rail to reach the Olympic Park (ODA, 2011). In fact, the Games had been promoted as the "public transport Games" (Interview, Allen, 2014), so it was essential that the transport system was kept running. The labelling of the Games in this way by the organisers undoubtedly increased the disruptive power of the RMT and other transport unions. The highly integrated nature of the London transport network means that is not substitutable by other services, which gives the RMT more leverage than unions in other sectors. If there is a strike in a train-operating company, it is not possible for a different company to put themselves forward as a substitute provider.

The figures on public transport use during the Games also demonstrate that the disruptive 
power of the RMT increased. Transport for London (2012b: 7) estimated that there would be three million extra journeys throughout the transport network on the busiest days of the Games. During the Olympics more than 62 million journeys were made on the London Underground, an increase in 35 per cent on normal usage. The busiest day in the history of the London Underground occurred on 7 August with 4.57 million users. There were about 6.4 million journeys on the London Overground during the Olympics, an increase of 54 per cent on 2011 levels. The increase in passenger numbers is even more striking on the Docklands Light Railway, where the 6.9 million journeys during the Olympic Games represented an increase of over 100 per cent. Again another record was set with usage exceeding 500000 for the first time in history on 3 August (Interview, Allen, 2014).

Not only was a functioning transport system essential to the successful delivery of the Olympics but the RMT also obtained disruptive power due to the limited timeframe of the Games. Transport became a highly perishable good, and since workers have more power the more perishable the goods they produce (Batstone, 1988: 228), the Olympics increased the effectiveness of the union's disruptive power. As Gregor Gall pointed out:

Batstone's disruptive power does fit well to the period of the Olympics. Think about it in terms of the perishability of a product or service, and in particular in transport. If you can't make your journey on that particular day, then going the day after isn't any good to you. If you go on strike in a biscuit factory the problem is that there are probably loads of biscuits that you may still have in the warehouse and there are probably loads in the shops, plus there are lots of other types of biscuits for people to eat. I mean civilization doesn't end just because there aren't any McVities Digestives in the supermarket. So you don't have the same kind of power (Interview, Gall, 2014).

A further source of disruptive power for the RMT was the ability of the union to damage the employers' reputation. This was multiplied during the Olympic period as not only was the reputation of the employer at stake but also that of the Olympic organisers and the Government. The global interest in the Games meant that no one wanted to be part of a failure, which also increased the disruptive power of the RMT. As Mark Evers, TfL Director of Customer Strategy and former TfL Director of Games Transport stated:

While we [transport] were going to play a very significant part in the Games we wanted to be almost an invisible part of that, certainly not be on the front page for the great transport success. The Games had to be about the sport and the only way we were ever really going to end up on the front page was if things went wrong... The world's media were watching during the torch relay looking for evidence of susceptibility and frailty in the transport network, so we were very much focused on making sure that the lead up was successful (Interview, Evers, 2014).

A significant source of the disruptive power of the RMT was that it is a highly organised union with high union membership and density figures, a high level of member engagement, a willingness of members to take industrial action and a track record of successful industrial action. The RMT membership in 2015 was 82256 (TUC, 2016), which is an increase of 22979 from the membership figure of 59277 when Bob Crow was elected (RMT, 2013). This is an annual increase of around 1767 , which is a big rise for a relatively small union. A focus on the organising agenda has also resulted in an increase in member involvement and the doubling of the number of Union 
Representatives from 2500 to 5000 since 2002. Furthermore, the high turnout in RMT ballots and a track record of successful industrial action increased their disruptive power. Such is the power of the RMT that often the threat of strikes will result in positive results. This was the case during the Olympics as most negotiations were settled after positive ballots, without resorting to industrial action.

The disruptive power of the Musicians' Union is far less than that of the RMT. Although entertainment was an essential part of the Games and industrial action by musicians would have had an impact on the delivery of the Games, there were a number of factors that meant that this disruptive power either could not materialis or was in fact reduced by the Olympics. First, unlike the RMT, the Musicians' Union is experiencing a downturn in membership, with a 7 per cent drop in membership from 2008 to 2012 (SERTUC, 2012). The union is a small one, with only 30262 members. Density in the arts and entertainment sector was also low at the time of the Olympics at only 14.8 per cent, 11.2 per cent below the national average. The collective bargaining coverage was also low, at 19.1 per cent, again below the national average by 10.2 per cent (Department of Business Innovation and Skills 2013: Tables 3.2 and 3.9).

Furthermore, the Musicians' Union does not have a tradition of taking or winning concessions through industrial action. While there were thirty-six stoppages in the transport sector in 2012, there were only three stoppages in the arts and entertainment sector, which was the second lowest sector overall (Office for National Statistics, 2013). The last significant strike organised by the Musicians' Union was in 1980, when 500 members of the British Broadcasting Corporation (BBC) took strike action against cuts at the Corporation, the casualisation of the musical labour force and the disbanding of five of its eleven orchestras, which resulted in 158 redundancies. The strike was only partially successful, as two of the five threatened orchestras were disbanded and many musicians lost their contracts with the BBC, having to work in future on a freelance basis (Williamson, 2014). Given this lack of an industrially successful track record, it is questionable whether the union would have been able to mobilise members to take action during the Olympics. One could also reasonably assume that the employer would not consider a threat of industrial action to be realistic or achievable. It is also questionable as to whether the union would have been able to mobilise behind the demand to receive payment, as performing for free is commonplace within the industry. In the year prior to the Olympics an estimated 60 per cent of musicians worked for free, as unpaid work is accepted by the industry as a way of enhancing future employment prospects (Musicians' Union, 2012b).

The fragmented and peripatetic nature of the music profession means that Musicians' Union members are less well organised than those belonging to the RMT, thus reducing their disruptive power. The majority of musicians do not have a permanent employer and many work on a freelance or self-employed basis. Half of musicians have no regular employment but of those that do only 10 per cent are full-time salaried employees while 94 per cent work freelance for all or part of their income (Musicians' Union, 2012b). In addition, for 34 per cent of musicians, performing is not their primary income source (Musicians' Union, 2012b), which means that they may not consider it important to even join the Union. Not only does this mean that there is no single employer for collective bargaining purposes but also that as there is no single workplace. Thus it is harder for the union to have contact with, recruit new, and organise existing members. Horace Trubridge explained:

I have to be honest and say that it's very, very difficult for us to take industrial action because the vast 
majority of our workforce are freelancers, so it's not like an organised workforce where, under the strict trade union rules that we all have to stick to, you can very easily do a ballot for industrial action, because we don't have workplaces (Interview, Trubridge, 2015).

The prestige attached to performing at the Olympics reduced the disruptive power of the Musicians' Union, as it would have been very difficult to organise solid industrial action since so many people wanted to be part of the Games and associated events. As Trubridge stated:

We know that there were professional musicians performing in the opening ceremony who weren't paid and who weren't going to benefit other than being able to say to their family and friends that they performed in the opening ceremony and a lot of musicians said that to me "I just wanted to do it" (Interview, Trubridge, 2015).

In addition the potential increase in exposure due to the high audience figures meant that musicians were keen to be part of the Games. The opening and closing ceremonies were each watched by 27 million people in the UK (Ofcom, 2012), and the potential exposure from these and other events reduced the union's potential disruptive power.

\section{Labour Scarcity Power}

The labour scarcity power of the RMT is far higher than that of the Musicians' Union. A high skillset and labour shortage, especially among engineers and drivers, is characteristic of the transport sector. Training for engineers in the transport sector is lengthy, and while it is possible to enter the profession via an apprenticeship scheme, many of them have a Bachelors or Masters degree in engineering. The training for train drivers is also rigorous and is continuous throughout a driver's career. While the national skills shortage for all sectors of the UK economy stands at 23 per cent, the skills shortage is 42 per cent for engineers and signalling technicians, 26 per cent for train drivers and 22 per cent for rail track maintenance workers (National Careers Service, 2014 a,b,c,d), which adds to the labour scarcity power of these occupational groups. In addition the fact that underground drivers are trained to cover just one underground line and one type of rolling stock increases their labour scarcity power. During a strike, underground drivers cannot be reallocated to different lines, limiting the power of the employer to manage the overall system during strikes.

The skills set required to be a musician does give the union some labour scarcity power. The music labour force is highly skilled, with 65 per cent of musicians completing at least four years of formal education and training, with half of these studying over seven years. The majority of musicians (61 per cent) completed their training at a dedicated music college, university or conservatoire, with 40 per cent having a music degree. Continual training is an essential part of the profession, with 55 per cent practicing for more than five hours per week and 37 per cent up to five hours per week (Musicians' Union, 2012b). However, despite this high level of training completed by many musicians, the skills shortage of musicians is only just above the national average of 24 per cent (National Careers Service, 2014e), which means that there are plenty of musicians able to perform, reducing the union's labour scarcity power. Furthermore, it is not necessary to have any formal qualifications to be a musician, and the use of amateur musicians is widespread, which significantly reduces the labour scarcity power of the union. As Horace Trubridge explains: 
There are always loads of musicians. You know the music colleges are so good in this country. They churn out such a fantastic calibre of musicians, all of whom want to make a career out of music and 90 per cent of them won't be able to.... There is massively more supply than demand and it is really due to the music colleges, which do a fantastic job, you know, the conservatoires and the music colleges just churn out a really hire calibre of musician.. For us it's very difficult. We are almost unable in every situation to consider any kind of traditional industrial action. We've got certain workforces such as the Royal Opera House in Covent Garden and major orchestras where it might be possible to still take the industrial action route but mostly we have to rely on our individual members holding a line and it's very difficult because, to use the analogy of a train driver, you either are a train driver and you're qualified or you're not, but with musicians there are amateur musicians who want to be professionals and there is this huge waiting-room of semi-professionals or part-time professionals who want to be full-time professionals and will perform for free or very little (Interview, Trubridge, 2015).

The labour scarcity power of the Musicians' Union was significantly reduced during the Olympics due to the existence of the Olympism philosophy, which portrays the Games as being about more than just sport but rather a socio-moral ideal or social aspiration to which people can contribute. This means that people volunteer in large numbers, to enable them to be part of this movement and "family" (MacAloon, 1999). Therefore, there are always many people willing to volunteer at the Games, including in the entertainment sector, which reduces the labour scarcity power of the Musicians' Union. As Paul Nowak, Assistant General Secretary of the TUC, explains:

The Musicians' Union is a really well organised union in many respects but if someone has the opportunity to perform at the Olympic Games they are going to take it. I mean, there were other groups of people who volunteered for the Games, such as physiotherapists, who were NHS professionals. They volunteered because they wanted to be working backstage at the 100 meters or working with Usain Bolt or whatever. That is what they want to do and for the union to say to them, "Well no actually, you can't do that" - well it's just not going to happen. That's different to a train driver, as there were obviously no volunteer train drivers. For some of the professions the line between voluntary and potentially paid work got blurred (Interview, Nowak, 2014).

Labour scarcity power was further reduced due to the normalisation of the use of volunteers to deliver the Games. Volunteer musicians have been seen as part of the "Olympic Family" and the "Global Village" since the inauguration of the modern Games in 1896. As William Guegold stated at the symposium on "Volunteers, Global Society and the Olympic Movement", organised by the Olympic Museum and the International Chair in Olympism in 1999:

Many thousands of musicians have donated their time and talents to the Olympic Games since 1896, helping unite the Global Village unlike any other event. Why would one want to do this? One must conclude that they continue to volunteer because of the ongoing attraction of the ideals present in the Olympic Spirit and Pierre de Coubertin's vision to include music and the other arts as an integral part of this truly worldwide spectacle. Why? Perhaps it is better to ask, who wouldn't? (Guegold, 1999).

\section{Political Power}

It is more difficult to quantify the political power of the RMT. However, a number of factors that 
contributed to potential political power of the union in the run-up to and during the Olympics are apparent. The main sources of the RMT's political power are their Parliamentary Group and also the potential impact that union action can have on public election results. The Olympics increased the political power of the RMT primarily due to these two power sources. Established in 2002, the Parliamentary Group is convened by John McDonnell, MP. It secured some victories before the Games, particularly around preventing the licensing of pedicabs, demonstrating the power of the Group. Policy on public transport in London has been a key electoral issue in previous elections. Especially the Conservative Party and London Mayor Boris Johnson, a Conservative, would have been aware that the disruption of the Olympics due to planned industrial action could have damaged their reputation and possibly their future electoral success. Strike action is often an electoral liability (Connolly and Darlington, 2012), which would have increased with the attention of the world on the UK and London. This added significantly to the political power of the RMT. In 2012 the London Mayor and London Assembly elections took place in May, just two months before the start of the Olympics, and the Games were inevitably an important electoral issue. The incumbent Mayor wanted to avoid industrial action before the elections and also wanted show that he was in control of the unions. Prior to the elections there were a number of arguments between Johnson and his challenger and former Mayor, Ken Livingstone, about the power of the unions and, in particular, about the RMT. During a debate on LBC Radio on 3 April 2012 both candidates criticised the power of the RMT in the run-up to the Olympics and argued that they were the candidate to ensure that there would be no strikes during the Games. The connection between the Olympics and the elections was even raised at a meeting of the Parliamentary Culture, Media and Sport Committee (2011), where a suggestion was made that the date of the elections should be changed.

A further source of union power is the ability to gain public support. Although there was no data on public opinion for the planned RMT industrial action during London 2012, the union has, on several occasions, shown its ability to gather popular support for industrial action, adding to its political power. During a twenty-four hour strike on the London Underground in September 2010 against planned redundancies, 60 per cent of the British public supported their right to strike (YouGov, 2010). During the 2014 strikes against large-scale closure of ticket offices on the London Underground, a survey of 1000 tube users showed that 60 per cent of respondents were concerned about the planned closures, 65 per cent believed that industrial action taken as a last resort was justified and 87 per cent agreed that the Mayor of London should speak with the trade unions concerned to reach a resolution (Survation, 2014).

The Musicians' Union obtains some political power from a number of sources. Prior to and during the Olympics the union was a member of the Performers' Alliance Parliamentary Group (now the Performers' Alliance All-Party Parliamentary Group), made up of the Musicians' Union, Equity and the Writers' Guild. Like the RMT, it also has its own Parliamentary Group, whose members raised questions in Parliament on the issue of the non-payment of musicians. Unlike the RMT, the Musicians' Union is affiliated to the Labour Party and is therefore able to have a more direct impact on the policies of the Labour Party. This parliamentary work has resulted in the Musicians' Union successfully lobbying political parties and governments on a number of issues, demonstrating some political power. Successes include the introduction of the Live Music Act (European Parliament legislation that makes it easier for musicians to take their instruments on planes), the Digital Economy Act and the Beijing Treaty, which achieved audio-visual rights for performers (Smith, 2014). Before the Olympics the union was able to force a response from the Department for Culture, 
Media and Sport on the issue of non-payment of professionals. However, the Department simply denied that professionals were being asked to perform for free, and stated that instances should be brought to its attention (Department for Culture, Media and Sport, 2012). The Musicians' Union did not win any binding commitments, showing the limited nature of its political power.

In addition, the union's inability to win public support on the issue of payment for musicians demonstrates the limitations of its political power. The acceptance of the use of volunteers at the Olympics not only reduced the labour scarcity power of the union during the Games but also its political power, as the public considered it an opportunity to be part of the Games and acceptable to play for free. A petition on the Change website to the Chief Financial Officer and Director of Ceremonies, Education and Live Sites obtained 4931 signatures, which is a relatively low amount (Change, 2012). There was also a Facebook page created - called "Musicians against Playing for Free at the Olympics" - which had 2500 members. This was successful in that it created a network for discussion and highlighting examples of non-payment which has continued until the present day. However, this was primarily an inward-looking group for musicians to discuss issues and did not succeed in involving members of the public in a campaign. These online initiatives were not organised by the Musicians' Union but demonstrate the limited public support for the issue. This was confirmed by Horace Trubridge:

I think the general public have got a malaise when it comes to unions anyway, and they were all so excited about the Olympics that it was like "Oh, another union moaning" kind of thing. I don't think there was mass support from the public. I think we got a lot more support from the media than we got from the actual public (Interview, Trubridge, 2015).

\section{Conclusion}

The differentials in what trade unions were able to negotiate for their members in the run-up to London 2012 can be explained by using Batstone's three-fold power schema. The outcomes of the negotiations were a reflection of the individual unions' pre-existing power. Those that had more disruptive, labour scarcity or political power prior to the Games were able to win more benefits for their members, whereas those with less power were either less successful or did not succeed at all in their negotiations. In addition, when evaluating the power sources, an "Olympic factor" can be observed, which produces a differentiated impact on the power resources of the unions.

The RMT has a particularly high level of disruptive power, which contributed the most to its ability to negotiate Olympic bonuses for most members. Sources of disruptive power included the strategic position of transport to the delivery of the Games, the potential loss of income and damaged reputation of the employer, high membership and density figures, high level of member engagement, a willingness of members to take industrial action and a track record of successful industrial action. The labour scarcity power of the RMT was also high, especially among engineers and drivers, where a high skill-set and training is required and where there is a labour shortage. The RMT also had a good level of political power, with the main sources being their Parliamentary Group and the potential impact that union action can have on public election results. The Olympics strengthened the RMT's power sources, in particular their disruptive power, due to the integral role 
played by transport in the success of the Games, the fact that the world's attention was on London and the set timeframe of the Olympics, which meant that transport became a highly perishable good.

While the main power source for the RMT during the Olympics, was its disruptive power, it would seem that the only power source for the Musicians' Union in the run-up to the Games was its political power, which it obtained through its involvement in its Parliamentary Group and its affiliation to the Labour Party. However, this potential was not realised, as demonstrated by the union's failure to influence the Department for Culture, Media and Sport and the inability to mobilise public support for its "Work not Play" campaign. In the case of the Musicians' Union, an "Olympic factor" can also be observed: The philosophy of Olympism and the emphasis on people volunteering to become part of the Olympic Movement or Family reduced all three of Batstone's power sources, most significantly the labour scarcity power of the Musicians' Union.

As the Olympics and other mega-sport events are held in many different countries with varying levels of labour rights and trade union organisation, it is not possible to recommend a uniform strategy for trade union approaches to such events. Strategic decisions based on unions' understanding of their power sources should be made. Unions need to analyse their existing and potential power sources and evaluate the possible impact of an "Olympic factor" which potentially alters the level of such power sources in the run-up to and during the Games to inform their decision how or whether to organise around Olympic Games. What is clear is that while the Olympics can increase the power of some trade unions and therefore offer some organising potential, they are not a golden opportunity for all.

\section{REFERENCES}

Batstone, E. (1988) The Frontier of Control. In Employment in Britain, edited by D. Gallie. London: Basil Blackwell.

Cashman, R. and A. Hughes (eds) (1999) Staging the Olympics: The Event and its Impact. Sydney: Centre for Olympic Studies, University of New South Wales Press.

Change (2012) LOCOG: Ensure the Payment of Arts Practitioners Performing for Olympic Events. Available online at https://www.change.org/ p / locog-ensure-the-payment-of-arts-practitioneersperforming-for-olympic-events (accessed 25 October 2015).

Connolly, H. and R. Darlington (2012) Radical Political Unionism in France and Britain: A Comparative Study of SUD-Rail and the RMT. European Journal of Industrial Relations, 18: 235-50.

Culture, Media and Sport Committee (2011) Minutes of Evidence London 2012 Olympic and Paralympic Games. 17 May 2011, Questions 187-261. Available online at http://www.publications.parliament.uk/pa/cm201012/cmselect/cmcumeds/689/11051702.ht $\underline{m}$ (accessed 18 August 2014).

Department of Business Innovation and Skills (2013) Trade Union Membership Statistics Tables. 3.2 and 3.9. Available online at https://www.gov.uk/government/publications/trade-union-statistics2012 (accessed 2 September 2014) .

Department for Culture, Media and Sport (2012) Payment/Non-payment of Performers at Olympic Ceremonies 17 July 2012. Available online at https://www.gov.uk/government/news/paymentnon-payment-of-performers-at-olympic-ceremonies (accessed 26 October 2015). 
Guegold, W.K. (1999) Volunteerism and Olympic Music Venues. Paper presented at the symposium on Volunteers, Global Society and the Olympic Movement. Organised by the Olympic Museum and the International Chair in Olympism, 24-26 November 1999, Lausanne.

Hiller, H. (1989) Impact and Image: The Convergence of Urban Factors in Preparing for the 1988 Calgary Winter Olympics. In The Planning and Evaluation of Hallmark Events, edited by G. Syme, B. Shaw, M. Fenton and W. Mueller. Farnham, Surrey: Gower.

International Olympic Committee (IOC) (2012) Factsheet London 2012 Facts \& Figures. Update November 2012. Lausanne: International Olympic Committee.

International Olympic Committee (IOC) (2013) Olympic Charter. Lausanne: International Olympic Committee.

London 2012 Equality and Diversity Forum (2013) Working towards an Inclusive Games 2011-12: The Fourth Annual Report of the London 2012 Equality and Diversity Forum. London: Greater London Authority.

MacAloon, J. (1999) Volunteers, Global Society and the Olympic Movement. Paper presented to symposium on Volunteers, Global Society and the Olympic Movement. Organised by the Olympic Museum and the International Chair in Olympism, 24-26 November 1999, Lausanne.

Musicians' Union (2012a) Will the London 2012 Olympics Benefit Musicians? Available online at www.musiciansunion.org.uk/Home/News/2012/Apr/Will-the-London-2012-Olympicsbenefit-musicians?feed $=801 \mathrm{abc} 79-\mathrm{dc} 9 \mathrm{c}-471 \mathrm{a}-85 \mathrm{ff}-4 \mathrm{a} 3 \mathrm{a} 36 \mathrm{bf} 8 \mathrm{a} 3 \mathrm{~b}$ (accessed 26 October 2015).

Musicians' Union (2012b) The Working Musician. London: DHA Communications/Musicians' Union.

National Careers Service (2014a) Job Profiles: Rail Engineering Technician. Available online at https://nationalcareersservice.direct.gov.uk/advice/planning/jobprofiles/Pages/railengineeringt echnician.aspx (accessed 22 July 2014).

National Careers Service (2014b) Job Profiles: Train Driver. Available online at https://nationalcareersservice.direct.gov.uk/advice/planning/jobprofiles/Pages/traindriver.aspx (accessed 22 July 2014).

National Careers Service (2014c) Job Profiles: Signalling Technician. Available online at https://nationalcareersservice.direct.gov.uk/advice/planning/jobprofiles/Pages/signallingtechni cian.aspx (accessed 22 July 2014).

National Careers Service (2014d) Job Profiles: Rail Track Maintenance. Available online at https://nationalcareersservice.direct.gov.uk/advice/planning/jobprofiles/Pages/railtrackmainte nanceworker.aspx (accessed 22 July 2014)

National Careers Service (2014e) Job Profiles: Classical Musician. Available online at https://nationalcareersservice.direct.gov.uk/advice/planning/jobprofiles/Pages/classic almusician.aspx (accessed 22 July 2014).

National Union of Rail, Maritime and Transport Workers (RMT) (2013) RMT Membership Increases as Attack on Jobs Continues. Available online at http://www.rmtlondoncalling.org.uk/content/rmtmembership-increases-attack-jobs-continues (accessed 29 January 2016).

National Union of Rail, Maritime and Transport Workers (RMT) (2014) About Us - Welcome to Britain's Largest Specialist Transport Trade Union. Available online at http://www.rmt.org.uk/about (accessed 29 April 2014). 
Office of Communications (Ofcom) (2012) The London 2012 Olympic Games: Media Consumption. London: Ofcom. Available online at: http://stakeholders.ofcom.org.uk/binaries/ consultations/london2012/media-consumption/report.pdf (accessed 4 January 2015).

Office for National Statistics (2012a) Labour Market Statistics, November 2012 Table AO7 Regional Summary of Labour Market Headline Indicators. Available online at http://www.ons.gov.uk/ons/publications/re-reference-tables.html?edition=tcm $\% 3 \mathrm{~A} 77222521$ (accessed 22 July 2014).

Office for National Statistics (2012b) Labour Disputes, Annual Article 2011, Released 15 August 2012. Available online at http://www.ons.gov.uk/ons/rel/bus-register/labourdisputes/annual-article2011/index.html (accessed 21 July 2014).

Office for National Statistics (2013) Labour Disputes, Annual Article 2012, Released 4 July 2013. Available online at http://www.ons.gov.uk/ons/rel/bus-register/labourdisputes/annual-article2012/index.html (accessed 21 July 2014).

Olympic Delivery Authority (ODA) (2011) Transport Plan for the London 2012 Olympic and Paralympic Games. Second edition. June 2011. London: ODA.

Olympic.org (2012) London 2012 Facts. Available online at http://www.olympic.org/london2012summer-olympics (accessed 22 July 2014).

Roche, M. (2000) Mega-events and Modernity: Olympics and Expos in the Growth of Global Culture. London: Routledge.

Southern and Eastern Regional Council of the TUC (SERTUC) (2012) Swimming against the Tide: SERTUC's Ninth Survey of Equality in Trade Unions. London: SERTUC.

Smith, J (2014) Being Political. In Unions and Democracy: A Unions 21 Debate Piece, edited by Dan Whittle. London: Unions 21.

Survation (2014) Underground Passenger Survey. London: Survation

Timms, J. (2012) The Olympics as a Platform for Protest: A Case Study of the London 2012 "Ethical" Games and Play Fair Campaign for Workers' Rights. Leisure Studies, 31(3): 355-72.

Transport for London (2012a) London 2012 Games Transport - Performance, Funding and Legacy. London: Transport for London.

Transport for London (2012b) Transport for London Annual Report and Statement of Accounts 2011/12. London: Transport for London.

Trades Union Congress (TUC) (2012) Principles of Cooperation between London 2012 and the Trades Union Congress, 3 September 2008. London: TUC.

Trades Union Congress (TUC) (2013) Assessment of Trade Union Involvement in London 2012 Olympic and Paralympic Games. Paper presented to the TUC Executive Committee EC 6/6 12 March 2013. London: TUC.

Trades Union Congress (TUC) (2016) TUC Directory 2016. London: TUC.

Waitt, G. (1999) Playing Games with Sydney: Marketing Sydney for the 2000 Olympics. Urban Studies, 36: 1055-77.

Williamson, J. (2014) The Strike That Made History. Available online at The Musicians' Union: A Social History: http://www.muhistory.com/?p=1075 (accessed 29 August 2014). 
YouGov (2010) London Underground Strike. Available online at
http://yougov.co.uk/news/2010/09/06/london-underground-strike (accessed 23 July 2014).

\section{Interviews}

Allen, Sharon. RMT Learning Development Worker, London. 4 August 2014.

Booth Janine. RMT Representative-Bank Group of Stations. RMT Representative on European Transport Federation Women's Committee. Formerly London Transport Region Representative of RMT Council of Executives. London, 3 August 2014.

Darlington, Ralph (Professor). Professor of Employment Relations, Director of Postgraduate Research, Salford Business School, University of Salford. Manchester, 8 August 2014.

Evers, Mark. Transport for London Director of Customer Strategy. Formerly TfL Director of Games Transport. London, 5 August 2014.

Gall, Gregor (Professor). Professor of Industrial Relations, School of Management, Bradford University and Visiting Lecturer, Hertfordshire Business School, University of Hertfordshire. Via Skype, 14 August 2014

Nowak, Paul. Assistant General Secretary, Trades Union Congress. London, 12 August 2014.

O'Hanlon, Dean. RMT Branch Secretary, Finsbury Park Branch. Second Stage Industrial Relations Representative on Trains Functional Committee. London, 12 August 2014.

Trubridge, Horace. Assistant General Secretary, Musicians’ Union. London, 21 October 2015.

\section{BIOGRAPHICAL NOTE}

HELEN RUSSELL is an alumna of the Global Labour University. She is currently the Trade Union Training Officer of the Chartered Society of Physiotherapy (CSP), the professional association and trade union for physiotherapists, physiotherapy students and support workers across the UK. She has previously worker for the British unions UNISON and NASUW'T - The Teachers' Union. [Email: helenback75@yahoo.co.uk] 